... Sujová, Hlaváčková, Marcineková: Evaluating the Competitiveness of Wood Processing...

Andrea Sujová ${ }^{1}$ Petra Hlaváčková ${ }^{1}$, Katarina Marcineková2

\title{
Evaluating the Competitiveness of Wood Processing Industry
}

\section{Vrednovanje konkurentnosti drvoprerađivačke industrije}

\author{
Original scientific paper • Izvorni znanstveni rad \\ Received-prispjelo: 5. 9. 2014. \\ Accepted-prihvaćeno: 6. 11. 2015. \\ UDK: $630 * 79$ \\ doi:10.5552/drind.2015.1432
}

\begin{abstract}
Wood processing industry (WPI) is a sector based on renewable natural resources of wood raw material. It can, therefore, provide sustainable growth and be competitive on the international markets. The interest of the European Union is to build economy based on renewable natural resources, meaning that it is necessary to pay increased attention to the development and support of the WPI. The aim of the article is to evaluate and compare the level and development of competitiveness of WPI in the Czech and Slovak Republics for a ten year period through the establishment of indicators based on foreign trade data of industry using mathematical and statistical methods. To reach the goal, a system of indicators measuring sectoral competitiveness was set up under the hypothesis: in the WPI the potential of competitiveness is used deficiently. The resulting indicators have confirmed the hypothesis and shown that, despite the fact that the WPI creates active foreign trade balance and contributes to surplus balance of the country, it achieves low values of indicators implying comparative advantage with a negative, decreasing trend, consequently meaning that industry gradually loses its competitive ability. The analysis also showed that the reason for low competitive ability of WPI is low specialization of the country in the commodity group, which was confirmed by statistical method of correlation analysis.
\end{abstract}

Key words: competitiveness, Revealed Comparative Advantage, foreign trade balance, wood processing industry

SAŽETAK • Drvoprerađivačka industrija (WPI) industrijski je sektor koji se temelji na drvnoj sirovini kao obnovljivome prirodnom resursu, zbog čega je moguće ostvariti održivi rast i razvoj te međunarodnu konkurentsku prednost. Interes je Europske unije graditi gospodarstvo utemeljeno na obnovljivim prirodnim resursima, što će rezultirati pojačanom pozornošću prema razvoju i potpori WPI-a. Cilj ovog rada jest vrednovati i usporediti razinu razvijenosti konkurentnosti WPI-a u Češkoj i Slovačkoj Republici u razdoblju od deset godina, i to uspostavom pokazatelja utemeljenih na podacima međunarodne trgovine sektora primjenom matematičkih i statističkih metoda. Kako bi se to postiglo, uspostavili smo sustav pokazatelja kojima se mjeri sektorska konkurentnost. Postavili smo hipotezu da je potencijal konkurentnosti WPI-a nedovoljno iskorišten. Rezultati dobiveni uz pomoć tih pokazatelja potvrdili su hipotezu i pokazali da, usprkos činjenici da WPI ima pozitivnu vanjskotrgovinsku bilancu i unatoč činjenici da znatno pridonosi pozitivnoj bilanci države, još uvijek ima niske vrijednosti pokazatelja, što upućuje na negativne trendove komparativnih prednosti, a posljedica toga je gubitak komparativnih mogućnosti. Analiza je također pokazala da je razlog niske konkurentnosti WPI-a niska specijaliziranost pojedine države u pojedinoj grupaciji proizvoda, što je potvrđeno statističkom metodom korelacijske analize.

Ključne riječi: konkurentnost, komparativne prednosti, vanjsko trgovinska bilanca, drvoprerađivačka industrija

\footnotetext{
${ }^{1}$ Authors are associate professor and assistant professor at Faculty of Forestry and Wood Technology, Mendel University in Brno, Brno, Czech Republic. ${ }^{2}$ Author is PhD. student at Faculty of Wood Sciences and Technology, Technical University in Zvolen, Zvolen, Slovakia.

Autorice su izvanredna profesorica i docentica Fakulteta šumarstva i drvne tehnologije, Mendelovo sveučilište u Brnu, Brno, Republika

Češka. ${ }^{2}$ Autor je doktorand Fakulteta znanosti o drvu i drvne tehnologije, Tehničko sveučilište u Zvolenu, Zvolen, Slovačka.
} 


\section{INTRODUCTION} 1. UVOD

According to EU, the competitiveness is defined as the ability of the firms, industries, regions, nations and transnational regions to generate a high level of income and employment, while exposed to foreign competition. Today, competitiveness of countries and industries on the world markets is the basis for the theory of international trade and economic growth, while in comparison with classical and neoclassical economic theory of international trade, it highlights innovative, realistic sources of trade and economic development. In professional literature, however, there is no universally valid and generally accepted definition for the competitiveness of the sector. In the case of sectoral competitiveness, the macro-economic evaluation of competitiveness is applied, thus there is an overlap of macro and meso level view of competitiveness. The balance of foreign trade is used for better understanding of competitiveness and it is, therefore, based on analyzing comparative advantages of the industry. At the sectoral level, an international trade is also taken into account.

The article deals with the analysis of competitiveness of wood processing industry (WPI) in the Czech Republic, Slovak Republic and comparison with EU WPI as a whole. The article is focused on WPI for several reasons. The WPI is extremely multi-functional and provides a wide range of products and materials. It provides economic, environmental and social contribution based on use of renewable resources. Wood-based products are recyclable, re-usable either as new products or energy. They are biodegradable and can be used to replace materials from non-renewable resources. The WPI is an important part of developing economies and provides a new prospective direction based on biotechnology. Production of wood-based products in the Czech and Slovak Republics has, in regard to sufficient supply of input wood material, long tradition and, as one of the options for obtaining renewable resources, it is closely connected with many sectors of the national economy (Jelačić et al., 2012). Wood processing industry is one of the sectors in which the Czech and Slovak economies can affect European markets by maximum use of their own resources. The need to deal with the theme of the article is mainly due to the fact that the EU puts emphasis on the economic development based on renewable resources. WPI, therefore, belongs to the supported and prospective industries and it is in the EU interest to make this sector highly competitive on the world market. The competitiveness of the WPI is, therefore, highly topical and important. Despite these facts, insufficient attention is paid to the analysis of competitiveness development of WPI, and so far no study of the subject has been published.

The aim of this article is to evaluate, based on competitiveness analysis, the competitiveness development of the wood processing industry in the Czech and Slovak Republics in a ten-year period, to identify competitive advantages of the industry and to suggest possibilities for increase of sectoral competitiveness within EU.

\section{MATERIAL AND METHODS} 2. MATERIJALI I METODE

The material required for achieving the relevant outputs from a secondary research was obtained on the basis of an analysis of available scientific literature dealing with competitiveness problem of sectors and countries and on the basis of processing the foreign trade statistics of the wood processing industry.

The present research of competitiveness is based on using statistical methods to assess revealed and anticipated comparative and competitive advantages. In fact, there is not only one indicator comprehensively expressing the level of competitiveness. Some indicators are applicable only to the whole economy; some may measure competitiveness at the level of a country as a whole as well as at lower levels of economic structure (Bobáková and Hečková, 2007). In practice, several indicators for identifying and measuring competitiveness, which can be combined, characterize competitiveness of the selected industrial sector or even country (Han et al., 2009). The indicators can be classified into two basic groups, to result-oriented and determinant-oriented indicators (Dieter and Englert, 2007).

Result-oriented indicators enable to detect a competitive situation in ex-post perspective and they are used for determining competitiveness in the sector and in international markets. Based on the study of literature and methodologies of international organizations dealing with the evaluation of competitiveness at the macro and meso levels, a system of indicators was developed for evaluating the competitiveness of the sector and its internal structure:

- Revealed Comparative Advantage (RCA) is the most used indicator and exists in several modifications:

- RCA indicator (Aiginger and Landesmann, 2002) expresses competitiveness at national level.

- Competitiveness Growth Index (RCA1) allows to determine the competitiveness of industry in the international and world market.

- Index of Net Business Performance RCA 2 (Balassa, 1965, p. 90-124) expresses the rate of the industry contribution to establish active trade balance.

- RCA index of cross-sectoral specialization (in accordance with the methodology ITC - International Trade Center UNCTAD and WTO) analyzes the difference between observed net exports, existing specialization, trade deficit and the theoretical net exports.

- Index of Contribution to Trade Balance CTB (Melíšek, 2012) measures the contribution made by the industry to the national trade balance.

- Michaely Index (Michaely, 1962) enables to demonstrate certain rate of specialization of the country in the commodity group, or in the industry.

- Grubel-Lloyd Index (GLI) analyzes the level of representation of commodities with intrasectoral character of foreign trade, higher levels of representation is symptomatic of higher level of national competitiveness. 
- Index of Kilogram Export and Import Prices (KPI) highlights the relationship between price and qualitative competitiveness of the product or commodity group.

- Indicator of revealed price elasticity (REVELAST approach) developed by Aiginger and Landesmann (2002) analyzes competitiveness in price and qualitative distinction.

The real competitiveness of wood processing industry, its sections and commodities was analyzed by applying the above mentioned methods for measuring competitiveness at the level of industry with the aim to validate correctness of the achieved results and the relevance of characteristics.

Indicators found in literature were modified and their calculation was adjusted in order to provide the analysis of sectoral competitiveness. For their calculation, the following abbreviations are used:

$x_{i j}$ - export value of commodity group , , i“ within industry , i“" in country , i“"

$m_{i j}$ - import value of commodity group „,i“ within industry , ,i" in country , $\mathrm{j}$ “"

$X_{j}$ - value of total export from country, ,j“

$M_{j}$ - value of total import to country , ,j"

$X_{i}$ - world export or export of integration group (e.g.

EU) in commodity group ,i“

$X$ - total world export or total EU export

RCA indicator presents comparative advantage or disadvantage of export and its competitive ability. The formula for its calculation is:

$$
\mathrm{RCA}=\ln \left[\left(x_{i j} / m_{i j}\right):\left(X_{j} / M_{j}\right)\right]
$$

The following applies to variable RCA:

$\mathrm{RCA}<0$ induces revealed comparative disadvantages in the commodity.

$\mathrm{RCA}>0$ indicates that there are revealed comparative advantages in the country for exported commodities of that industry or commodity group.

RCA $>1$ identifies the commodity and industry as internationally competitive.

Index of Competitiveness Growth (RCA1) is calculated as follows:

$$
\mathrm{RCA} 1=\frac{x_{i j}}{X_{j}} / \frac{X_{i}}{X}
$$

If $\mathrm{RCA} 1>1$ there is comparative advantage of industry in the worldwide market

If RCA1 < 1 a commodity group has no competitive ability in the relevant market

Indicator of net trade performance (RCA 2) evaluates a comparative advantage of export of industry or commodity and its competitive ability. The formula for calculating RCA2 is:

$$
\mathrm{RCA} 2=\frac{x_{i j}-m_{i j}}{x_{i j}+m_{i j}}
$$

The following applies to variable RCA2:

$\mathrm{RCA} 2=-1$ means that there is no export $\left(x_{i j}=0\right)$, $-1<\mathrm{RCA} 2<0$ induces comparative disadvantage, RCA2 $=0$ export $=$ import

$0<\mathrm{RCA} 2<1$ induces comparative advantage,

$\mathrm{RCA} 2=1$ means that there is no import $\left(m_{i j}=0\right)$.
Michaely Index (MI) highlights the degree of specialisation, or the lack of specialisation in specific commodity groups. Calculation of the index is as follows:

$$
\mathrm{MI}=\frac{x_{i j}}{\sum_{i=1}^{n} X_{j}}-\frac{m_{i j}}{\sum_{i=1}^{n} M_{j}}
$$

The following applies to Michaely Index:

$0<\mathrm{MI}<1$ points to a certain degree of specialisation of the country in the commodity group,

$-1<\mathrm{MI}<0$ indicates insufficient specialisation of the country in the commodity group.

Index of Contribution to Trade Balance (CTB) is calculated by the formula:

$$
\mathrm{CTB}=\frac{x_{i j}-m_{i j}}{X_{j}+M_{j}}-\frac{X_{j}-M_{j}}{X_{j}+M_{j}} \cdot \frac{x_{i j}+m_{i j}}{X_{j}+M_{j}} \cdot 100
$$

The left part of the equation represents the real balance of trade industry based on its share in the total foreign trade of the country, which is a cross-sectoral trade, and the right part of the equation measures the expected trade balance in the sector (commodity group) provided that each commodity contributes to the overall trade balance according to their weight in total trade. The difference between the actual and the expected trade balance defines a specific contribution to the total trade balance.

The following applies to CTB:

CTB $>0$ means that actual surplus is higher than expected and the relative trade deficit is less than expected, the industry has a positive contribution to the overall trade balance,

$\mathrm{CTB}<0$ industry has a negative contribution to the total trade balance, the actual results are in accordance with the expected negative or insufficient results.

The original Grubel-Lloyd Index (GLI) measures export ability on the macroeconomic level. It has been modified for the evaluation at the industry level, and its calculation indicates the level of commodity representation in intrasectoral foreign trade of the country. The formula for its calculating is:

$$
\mathrm{GLI}=1-\frac{\frac{x_{i j}}{X_{j}}-\frac{m_{i j}}{M_{j}}}{\frac{x_{i j}}{X_{j}}+\frac{m_{i j}}{M_{j}}}
$$

Values of GLI are in interval from 0 to $1(0<$ $\mathrm{GLI}<1)$. Comparing value should be an average value of GLI for all industries in the country or GLI value of EU or world trade in the commodity group.

To simplify the comparison of the results of the sector in different countries, as well as for the purpose of implementing benchmarking, a new indicator has been suggested: Trade Coverage Index (TCI). Its calculation is presented in the section - Results.

Calculation of individual indicators was applied in the wood processing industry of the Czech Republic, the Slovak Republic and the EU 27. A characteristic feature of the WPI is processing of raw wood and wood products production at various stages of finalization. Within the classification of business activities of the EU (NACE), WPI consists of the following sections: 
- NACE 16: primary mechanical wood processing (timber industry),

- NACE 17: primary chemical wood processing (pulp and paper industry)

- NACE 31: secondary wood processing (production of furniture)

Input data for evaluating the competitiveness of WPI was obtained from the database of Statistics Bureaus, the Ministries of Economy of the Czech and Slovak Republics (www.cso.cz; www.slovak.statistics.sk) and Eurostat (epp.eurostat.ec.europa.eu) with annual data on foreign trade of countries and commodity structure divided according to statistical classification of products by activity (CPA 2008) in million Euro (FOB/FOB) for the period 2003 - 2012. The selected database enabled to exclude the trade in timber used as raw material from export and import values. Thus it was possible to analyze competitiveness of WPI according to the NACE.

To reach the goal of the paper, the hypothesis "WPI potential of competitiveness is used deficiently" was tested.

For appropriate applications of statistical methods, the application was created in MS Excel and competitiveness of WPI and its individual sections was analyzed at several levels: at international EU level, at national level and intrasectoral competitiveness of individual sections by calculating statistical variables to measure competitiveness. Then, the results obtained in the Czech and Slovak Republics were compared with the EU WPI as a whole. Moreover, a trendline analysis of competitiveness development has been performed.

Dependences among the selected data were analyzed using statistical method of correlation analysis. Strength of mutual dependence between selected relations was determined by calculating the coefficient of correlation $(r)$.

\section{RESULTS}

\section{REZULTATI}

The starting point in evaluating the competitiveness at the sector level was the definition that competitiveness of the industry can be characterized as the success of the industry in a competitive battle with other equivalent sectors in other economies in placing their products on the domestic and foreign markets, provided that production factors are efficiently used.

The status of wood processing industry (WPI) in the foreign trade of the country is characterized by the proportion of the sector in the foreign trade of the country, and its success in foreign markets is presented by export performance of the industry. The analyzed statistical data showed that in a ten year period (20032012) WPI in the Slovak and Czech Republics had an active role in the balance of trade; the export performance in Slovakia being much higher. The share of the Slovak WPI in the import of SR is lower than in the export and it gradually decreased from $4 \%$ to $2.9 \%$. In the Czech Republic the situation is similar, and the proportion of WPI in the Czech Republic is almost at the same level as in Slovakia. As for export performance of the industry, it can be concluded that in Slovakia it is high and amounting to an average of $77 \%$ of revenues and $95 \%$ of production. In the Czech Republic the export performance of WPI compared to SR is lower but with an increasing trend; the share of exports in sales gradually increased from $31.2 \%$ to $64.5 \%$ and in the production of WPI from $53.8 \%$ to $66.7 \%$.

\subsection{Analysis of Competitiveness of Wood} Processing Industry

3.1. Analiza konkurentnosti drvoprerađivačke industrije

The choice of indicators of competitiveness at the sectoral level was inspired by efforts to determine whether the wood processing industry and its sections have succeeded in the domestic and foreign markets. Evidence of success is a higher volume of products placed by the domestic industry on the foreign market than the volume of products placed by the same foreign sectors on the domestic market. Based on the information on these facts via the coefficient of RCA and its various modifications, coefficients CTB, GLI and Michaely Index were achieved. The achieved results of individual parameters are shown in Table 1.

Values of the indicators in Table 1 show that wood processing sector has a comparative advantage within the industry of the country, as well as on international markets. Positive values of RCA index mean a comparative advantage of the industry at the national level. However, over the analyzed period this advantage is gradually decreasing in both countries and approaching zero. In Slovakia it is associated with decreased net export of the sector, but in the Czech Republic, despite an increase in net exports, the comparative advantage decreases. Index of Competitiveness Growth (RCA1) is much higher than the value; in both countries it is almost at the same level and presents a high competitiveness of Czech and Slovak industry within the EU.

Positive values of net trade performance indicator (RCA2) say that WPI contributes to the positive trade balance of the sector, in Slovakia at a much higher rate than in the Czech Republic at the beginning of the period. However, in 2012 the situation was reversed due to a steep decrease in the Slovak Republic - up to three times, while in the Czech Republic, the level of indicator is almost at the same level. The indicator RCA2 is related to index of Contribution to Trade Balance (CTB) indicating the contribution of the sector to the national trade balance. The negative CTB values achieved in WPI as a whole and also in its subsectors since 2005 show that the contribution of the sector to the overall trade balance is negative and that there is no real surplus, which is quite the contrary of what was expected. This in turn means that the relative trade deficit is smaller than expected. Significantly worse results of this indicator were observed in the Czech Republic, where negative values have been recorded since 2005. Positive values of Michaely Index confirmed the competitiveness of WPI, but showed a very low rate of country specialization in the commodities 
... Sujová, Hlaváčková, Marcineková: Evaluating the Competitiveness of Wood Processing...

Table 1 Indicators of Competitiveness of Wood Processing Industry

Tablica 1 Pokazatelji konkurentnosti drvoprerađivačke industrije

\begin{tabular}{|l|c|c|c|c|c|c|c|c|c|c|c|}
\hline $\begin{array}{l}\text { indicator/ year } \\
\text { pokazatelj/godina }\end{array}$ & $\mathbf{2 0 0 3}$ & $\mathbf{2 0 0 4}$ & $\mathbf{2 0 0 5}$ & $\mathbf{2 0 0 6}$ & $\mathbf{2 0 0 7}$ & $\mathbf{2 0 0 8}$ & $\mathbf{2 0 0 9}$ & $\mathbf{2 0 1 0}$ & $\mathbf{2 0 1 1}$ & $\mathbf{2 0 1 2}$ \\
\hline WPI SR / WPI Slovačka \\
\hline RCA & 0.666 & 0.553 & 0.605 & 0.430 & 0.367 & 0.451 & 0.514 & 0.395 & 0.329 & 0.208 \\
\hline RCA1 & 1.984 & 1.953 & 1.965 & 1.949 & 1.763 & 1.712 & 1.940 & 1.695 & 1.642 & 1.527 \\
\hline RCA2 & 0.310 & 0.252 & 0.266 & 0.189 & 0.175 & 0.208 & 0.248 & 0.194 & 0.166 & 0.131 \\
\hline MI & 0.038 & 0.029 & 0.029 & 0.020 & 0.016 & 0.017 & 0.022 & 0.015 & 0.011 & 0.007 \\
\hline GLI & 0.679 & 0.731 & 0.706 & 0.788 & 0.819 & 0.778 & 0.748 & 0.805 & 0.837 & 0.897 \\
\hline CTB & 0.091 & 0.113 & 0.161 & 0.118 & 0.035 & 0.063 & 0.026 & 0.013 & -0.005 & -0.087 \\
\hline WPI ČR/ WPI Češka: \\
\hline RCA & 0.406 & 0.358 & 0.346 & 0.330 & 0.306 & 0.230 & 0.148 & 0.239 & 0.230 & 0.197 \\
\hline RCA1 & 1.895 & 1.812 & 1.793 & 1.707 & 1.659 & 1.613 & 1.659 & 1.621 & 1.614 & 1.587 \\
\hline RCA2 & 0.177 & 0.170 & 0.182 & 0.173 & 0.169 & 0.128 & 0.110 & 0.143 & 0.148 & 0.150 \\
\hline MI & 0.021 & 0.017 & 0.016 & 0.014 & 0.013 & 0.009 & 0.006 & 0.009 & 0.008 & 0.007 \\
\hline GLI & 0.800 & 0.823 & 0.829 & 0.836 & 0.848 & 0.886 & 0.926 & 0.881 & 0.886 & 0.902 \\
\hline CTB & 0.137 & 0.044 & -0.040 & -0.033 & -0.069 & -0.051 & -0.152 & -0.089 & -0.119 & -0.181 \\
\hline
\end{tabular}

and a decreasing trend in the post-crisis period. On the other hand, the values of the Grubel-Lloyd Index (GLI) show a high degree of representation commodities of intrasectoral character of foreign trade and an increasing share of individual WPI subsectors. GLI values of WPI are higher when compared with the average values of the processing industry of SR (0.835), CR
(0.868) and EU-27 (0.776), which implies WPI contribution to the competitiveness of economy as a whole.

Development trend of competitive abilities of wood processing industry based on the most important indicators are shown in Figures 1 and 2.

The development of the main indicators shows higher competitiveness of wood processing industry in

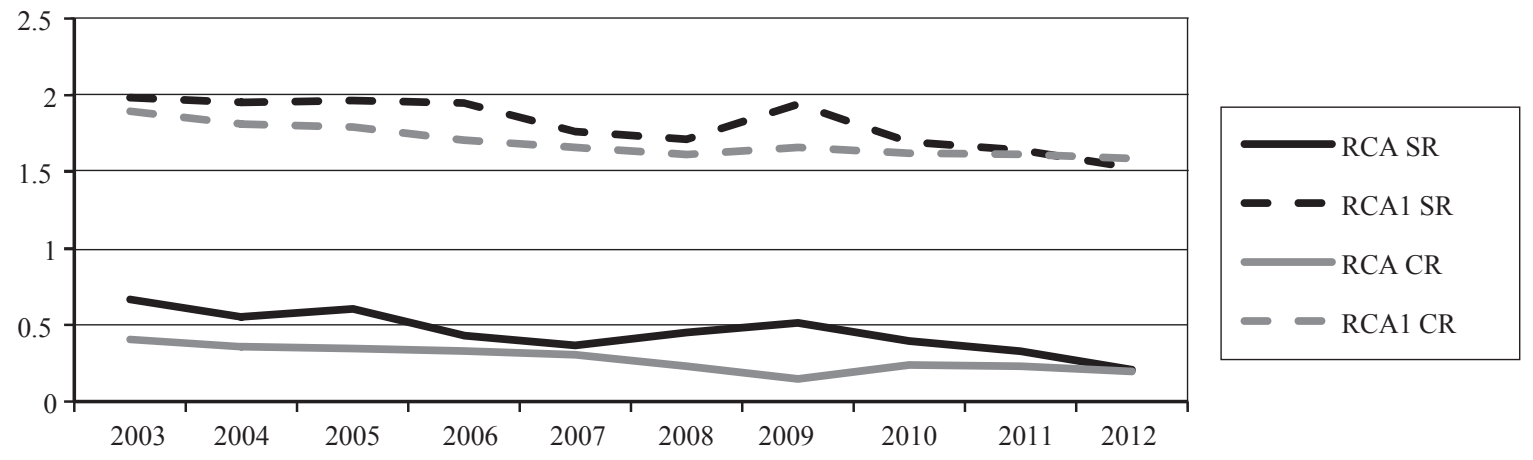

Figure 1 Trend of Revealed Comparative Advantage (RCA and RCA1)

Slika 1. Trend RCA, RCA1

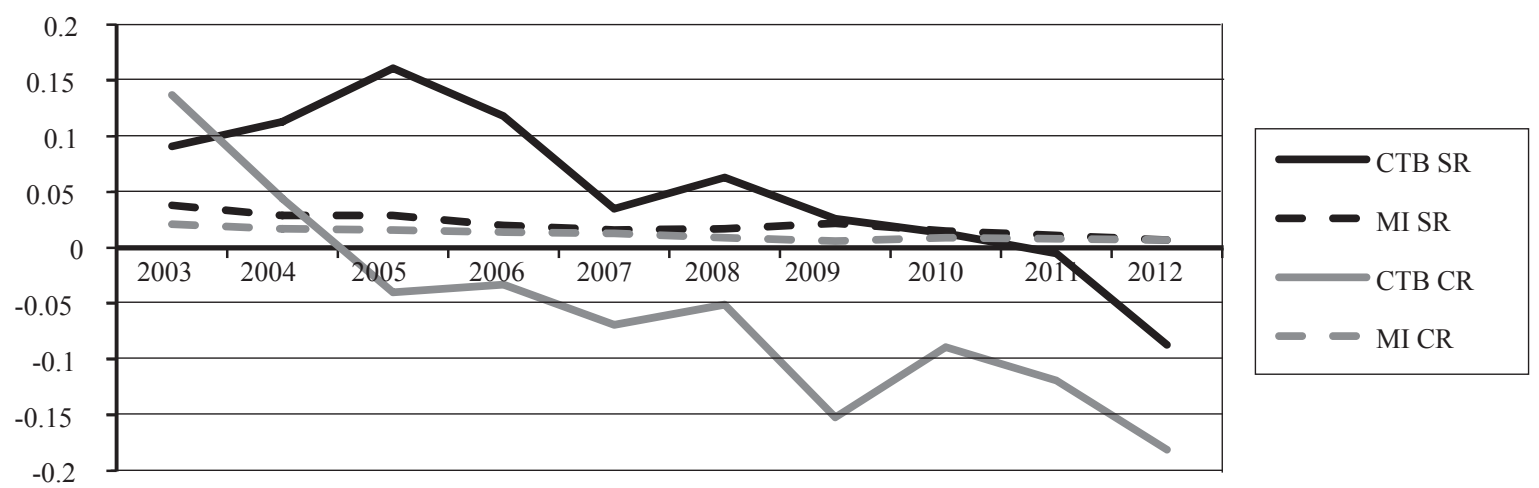

Figure 2 Trend of Contribution to Trade Balance Index (CTB) and Michaely Index (MI)

Slika 2. Trend CTB, MI 
Table 2 Correlation coefficients

Tablica 2. Koeficijenti korelacije

\begin{tabular}{|l|c|c|c|c|}
\hline$X / \boldsymbol{Y}$ & RCA & RCA1 & RCA2 & CTB \\
\hline MI & 0.9428 & 0.7815 & $\mathbf{0 . 9 3 1 9}$ & $\mathbf{0 . 9 5 7 2}$ \\
\hline GLI & $\mathbf{0 . 9 9 9 8}$ & 0.7959 & $\mathbf{0 . 9 6 6 6}$ & 0.8132 \\
\hline trade balance of WPI / trgovinska bilanca WPI- $a$ & $\mathbf{0 . 9 5 7 6}$ & 0.7428 & $\mathbf{0 . 9 2 6 3}$ & 0.765 \\
\hline $\begin{array}{l}\text { share of WPI in national export } \\
\text { udio WPI- } \text { a u nacionalnom izvozu }\end{array}$ & 0.8598 & 0.8098 & 0.8362 & $\mathbf{0 . 9 5 0 1}$ \\
\hline
\end{tabular}

Slovakia than in the Czech Republic. However, Slovak sector is losing competitiveness on foreign markets. If such trend continues, it can cause uncompetitiveness of Slovak WPI. Considering the development of CTB indicator, a negative trend can be seen. Despite higher values of RCA2 of WPI in SR compared to CR, the level of indicators was gradual falling and came under the EU average. A decreasing trend is also seen by Michaely Index, which is near zero.

In further analysis, findings of dependency between the selected indicators were analyzed using statistical correlation method to determine the factors affecting the competitiveness of wood processing industry. Dependences based on the correlation coefficients are shown in Table 2.

The results show that the sector's competitiveness is strongly influenced by the following factors:

- specialization of the country for commodities of the sector,

- high rate of intrasectoral foreign trade of the country,

- export performance of the sector at the national level,

- share of the sector in the country's export affecting mainly a positive contribution of the sector to active trade balance of the country.

\subsection{Comparative and Trendline Analysis of Competitiveness of Wood Processing Industry}

3.2. Analiza konkurentnosti drvoprerađivačke industrije komparacijom i na osnovi trendova

To compare the competitiveness of the sector in several countries, a new indicator Trade Coverage Index (TCI) has been proposed. The formula for its calculation is:

$$
\mathrm{TCI}=\ln \left[\frac{X_{i a}}{X_{i b}} / \frac{M_{i a}}{M_{i b}}\right]
$$

Where: $X_{i a}$ is export of sector , ,i $i^{\text {c }}$ and $M_{i a}$ import of sector,$i^{i c}$ in country,$a^{6 "}$

$X_{i b}$ is export of sector , $i^{* 6}$ and $M_{i a}$ import of sector,$i^{“}$ in country,$b^{\prime \prime}$

The following applies to TCI:

- $\quad$ if TCI $>0$ the higher competitiveness of the sector is in country ,,$a^{\text {“ }}$

- $\quad$ if TCI $<0$ the higher competitiveness of the sector is in country ,,$b^{\text {“ }}$

Results of TCA indicator calculated for comparison of Slovak and Czech wood processing industry are shown in Table 3. The values of Trade Coverage Index observed for WPI in Slovakia and the Czech Republic show that higher competitiveness of the sector was reached in Slovakia until 2011. However, this advantage was gradually decreasing until 2012 when the CR became more competitive. The low TCI values of 0.5 further indicate a small difference between competitiveness of the sector in Slovakia and the Czech Republic.

Competitiveness of the wood processing industry of the Czech and Slovak Republics at EU level was further evaluated by comparing the average values of indicators to WPI of EU as a whole. Results are shown in Table 4 and Figure 3. The comparison showed that, except indicators RCA2 and GLI, the Czech and Slovak WPI show lower competitiveness than WPI of EU. The most important indicators of competitiveness: RCA, MI and CTB are considerably below the EU average.

\section{DISCUSSION \\ 4. RASPRAVA}

Evaluating the competitiveness of wood processing industry was based on the findings of previous studies in which the authors (Sujová, 2011, 2012, 2013; Hlaváčková and Šafař́k, 2014) and other professionals (Parobek, 2014; Grladinović et al., 2006; Šafařík and Badal, 2013) dealt with qualitative analysis of com-

Table 3 Trade Coverage Index in wood processing industry of SR and CR

Tablica 3. Indeksi trgovinske pokrivenosti drvoprerađivačke industrije u Slovačkoj i Češkoj

\begin{tabular}{|l|c|c|c|c|c|c|c|c|c|c|}
\hline Years / Godine & $\mathbf{2 0 0 3}$ & $\mathbf{2 0 0 4}$ & $\mathbf{2 0 0 5}$ & $\mathbf{2 0 0 6}$ & $\mathbf{2 0 0 7}$ & $\mathbf{2 0 0 8}$ & $\mathbf{2 0 0 9}$ & $\mathbf{2 0 1 0}$ & $\mathbf{2 0 1 1}$ & $\mathbf{2 0 1 2}$ \\
\hline $\begin{array}{l}\text { TCI SR/CR } \\
\text { TCI Slovačka/Češka }\end{array}$ & 0.284 & 0.174 & 0.179 & 0.034 & 0.012 & 0.165 & 0.287 & 0.105 & 0.037 & -0.038 \\
\hline
\end{tabular}

Table 4 Average values of indicators

Tablica 4. Prosječne vrijednosti pokazatelja

\begin{tabular}{|l|c|c|c|c|c|c|}
\hline Indicator / Pokazatelj & RCA & RCA1 & RCA2 & GLI & CTB & MI \\
\hline WPI SR / WPI Slovačka & 0.452 & 1.813 & 0.214 & 0.779 & $\mathbf{0 . 0 5 3}$ & 0.020 \\
\hline WPI CR / WPI Češka & 0.279 & 1.696 & 0.155 & 0.862 & -0.055 & 0.012 \\
\hline WPI EU 27 & 1.070 & - & 0.159 & 0.776 & 0.154 & 1.028 \\
\hline
\end{tabular}




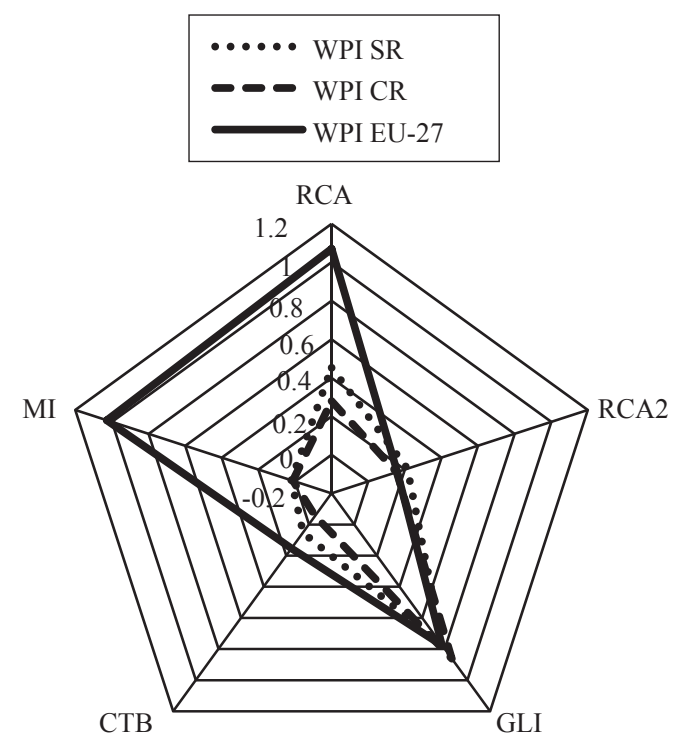

Figure 3 Comparison of competitiveness of WPI of SR, CR and EU 27

Slika 3. Komparacija konkurentnosti drvoprerađivačke industrije Slovačke, Češke i EU-a

petitive factors of wood processing industry. Previous analyses led to conclusions that wood processing industry has a high export performance compared to other sectors of industry and a significant share in production of processing industries. It is an independent industry based on imported raw wood material, but the use of wood raw material is not effective and the main competitive advantage of the industry is in the price and lower costs.

Quantitative analysis of the evolution of competitiveness of wood processing presented in this paper showed that the industry is competitive on a national and international level as well as at EU level. This is the result of the industry's ability to generate trade balance surplus. On the other hand, however, its real contribution to the national trade balance is negative. Previous qualitative studies confirmed the competitive ability of WPI and potential to be successful on the international market by increasing its performance and thus contributing to the sustainable growth of the national economy. According to the presented quantitative analysis, the competitiveness of an industry increases with the growth of positive net exports. However, the Slovak WPI has been losing this capability, and this may be caused by several factors: lower prices, decrease in the exported commodities or increase in imports of commodities of WPI.

In the way of achieving and demonstrating competitiveness, there is a conflict between the desire of the Government to maximize the utilization of domestic timber commodities and competitiveness on international markets based on foreign trade. To solve this problem, the country should specialize in foreign trade to create positive balance by means of sector's products with the highest added value.

Wood processing industry includes three subsectors. Production occurs in all stages of wood processing from the lowest up to the highest added value. The subject of further scientific study will, therefore, be intrasectoral analysis of competitive abilities of individual WPI sections allowing to suggest and optimize the structure of foreign trade in wood processing industry to increase competitiveness of the sector.

\section{CONCLUSION \\ 5. ZAKLJUČAK}

The wood processing industry has the potential to achieve high competitiveness on international markets, create an active trade balance and contribute to economic growth of the sector and country. The system of indicators established to analyze the level and evolution of competitiveness of the industry in a ten-year period enabled to determine the achieved comparative advantages and the ability to create a positive trade balance by wood processing industry. However, this cannot be applied in defining the active trade balance of the country, where the contribution is much lower than expected. At the beginning of the analyzed period, wood processing industry achieved higher competitiveness in Slovakia than in the Czech Republic, but after gradual decreasing indicators in Slovakia, at the end of the period in question the level was equal in both countries. It can be expected that competitiveness of wood processing industry in the Czech Republic will be kept at a low level, while the industry in Slovakia will be at risk of losing comparative advantage.

As for the competitiveness level of wood processing industry, the analysis showed existing comparative advantages but the achieved level of competitiveness is at a low level, lower than the EU average and the potential of the industry. The analysis confirmed very low specialization of countries in the WPI foreign trade and inability of industry to actively contribute to national trade balance, resulting in a decrease of existing comparative advantages of industry on international markets.

In order to influence trade balance in a positive way, it is necessary to optimize the structure of intrasectoral foreign trade, to increase attention to supporting export of wood-based products with the highest added value and exploit the potential of the industry to create a competitive advantage based on quality and innovation. Success of wood processing industry, therefore, lies in the active development of new comparative advantages because, as shown by the results of the analysis, the original comparative and competitive advantages based on cost and price are disappearing.

\section{REFERENCES}

\section{LITERATURA}

1. Aiginger, K.; Landesmann, M., 2002: Competitive Economic Performance: The European View [WIFO Working Papers 179/2002]. Wienna: Austrian Institute of Economic Research.

2. Balassa, B., 1965: Trade Liberalisation and Revealed Comparative Advantage. Manchester: Manchester School of Economics and Social Studies. 
3. Bobáková, V.; Hečková, J., 2007: Analýza konkurencieschopnosti slovenského spracovatel'ského priemyslu. Politická ekonómie, IV (4): 490-507 http://dx.doi.org/10.18267/j.polek.610.

4. Dieter, M.; Englert, H., 2007: Competitiveness in the global forest industry sector: an empirical study with special emphasis on Germany. Springer Link, 126 (3): 401$412 \mathrm{http}: / / \mathrm{dx}$.doi.org/10.1007/s10342-006-0159-x.

5. Grladinović, T.; Jelačić, D.; Motik, D.; Drabek, J., 2006: Modelling of the Material Flows IN Wood Industry Companies. Wood research, 51 (2): 63-75.

6. Han, X.; Wen, Y.; Kant, S., 2009: The global competitiveness of the Chinese wooden furniture industry. Forest Policy and Economics, 11 (8): 561-569 http://dx.doi. org/10.1016/j.forpol.2009.07.006.

7. Hlaváčková, P.; Šafařík, D., 2014: Problémy českých dřevozpracujících podniků a indikátory konkurenceschopnosti. Manažment podnikov, 4 (1): 3-8.

8. Jelačić, D.; Moro, M.; Drábek, J.; Sujová, A., 2012: Motivation factors in wood processing plants. Wood Research, 57 (2): 317-330.

9. Melíšek, I., 2012: Meranie a hodnotenie makroekonomických výsledkov zahraničného obchodu. Ekonomické rozhl'ady, 41 (4): 439-451.

10. Michaely, M., 1962: Concentration in International Trade, Contributions to Economic Analysis. Amsterdam: North-Holand Publishing Company.

11. Parobek, J.; Kalamárová, M., 2014: Kvantitatívne metódy konkurencieschopnosti zahraničného obchodu $\mathrm{s}$ drevom a výrobkami z dreva. Manažment podnikov, 4 (1): 9-14.

12. Sujová, A., 2011: Process restructuralization and its importance by increasing a competitiveness of an enterprise. Acta Univ. Agric. Silvic. Mendelianae Brunensis, 59 (2): 319-324 http://dx.doi.org/10.11118/actaun201159020319.

13. Sujová, A.; Rajnoha, R., 2012: Evaluation of competitive factors in Slovak woodprocessing enterprises as the base for business performance management. In: Wood and Furniture Industry in times of change - new trends and challenges: proceedings of the International Scientific Conference WoodEMA, Trnava: University of st. Cyril and Mehod in Trnava, pp. 1-6.

14. Sujová, A., 2013: Business Process Performance Management - A Modern Approach to Corporate Business Management. In: Liberec Economic Forum 2013: proceedings of scientific papers. Liberec: TU Liberec, pp. 542-550.

15. Šafařík, D.; Badal, T., 2013: The economic efficiency of forest energy wood chip production in regional use - A case study. Acta Univ. Agric. Silvic. Mendelianae Brunensis, 61 (2): 1391-1398 http://dx.doi.org/10.11118/actaun201361051391.

16. *** Czech Statistical Office. (C) 2014. [online]. Available at: <http://www.czso.cz $>$. [Accessed: 2014, March, 14].

17. *** EUROSTAT. (C) 2014. [online]. Statistics Database. European Commission. Available at: <http://epp.eurostat.ec.europa.eu/>. [Accessed: 2014, March, 10].

18. ***Statistical Office of the Slovak Republic. (C) 2014. [online]. Available at: $<$ http:// slovak.statistics.sk $>$ [Accessed: 2014, March, 20].

\section{Corresponding address:}

Assoc. Prof. ANDREA SUJOVÁ, PhD.

Department of Forest and Wood Products Economics and Policy

Faculty of Forestry and Wood Technology

Mendel University in Brno

Zemědělská 3

61300 Brno, CZECH REPUBLIC

e-mail: andrea.sujova@mendelu.cz 